\title{
Witchcraft, Gender and \\ Society in Early Modern Germany
}




\title{
Studies in
}

\section{Medieval and Reformation Traditions}

\author{
History, Culture, Religion, Ideas
}

\author{
Founded by \\ Heiko A. Oberman $\uparrow$ \\ Edited by \\ Andrew Colin Gow \\ Edmonton, Alberta \\ In cooperation with \\ THOMAS A. BRADY, JR., BERKELEY, GALIFORNIA \\ JOHANNES FRIED, FRANKFURT \\ BRAD GREGORY, NOTRE DAME, INDIANA \\ BERNDT HAMM, ERLANGEN \\ SUSAN G. KARANT-NUNN, TUGSON, ARIZONA \\ JÜRGEN MIETHKE, HEIDELBERG \\ M.E.H. NIGOLETTE MOUT, LEIDEN
}

VOLUME 124 


\title{
Witchcraft, Gender and Society in Early Modern Germany
}

\author{
By \\ Jonathan B. Durrant
}

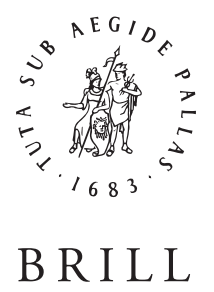

LEIDEN • BOSTON

2007 
B R I L L This is an open access title distributed under the terms of the CC-BY-NC License, OPEN which permits any non-commercial use, distribution, and reproduction in any medium, provided the original author(s) and source are credited. working with Knowledge Unlatched. More information about the initiative can be found at www.knowledgeunlatched.org.

On the cover: Daniel Hopfer, 'Peasants at a village feast', sixteenth century, woodcut. Germanisches Nationalmuseum, Nuremberg [ Inv. Nr. 11372 Kps. 1466]. Reproduced with kind permission.

ISSN $1573-4188$

ISBN 9789004160934

(c) Copyright 2007 by Koninklijke Brill NV, Leiden, The Netherlands.

This work is published by Koninklijke Brill NV. Koninklijke Brill NV incorporates the imprints Brill, Brill Hes \& De Graaf, Brill Nijhoff, Brill Rodopi and Hotei Publishing.

Koninklijke Brill NV reserves the right to protect the publication against unauthorized use and to authorize dissemination by means of offprints, legitimate photocopies, microform editions, reprints, translations, and secondary information sources, such as abstracting and indexing services including databases. Requests for commercial re-use, use of parts of the publication, and/or translations must be addressed to Koninklijke Brill NV.

This book is printed on acid-free paper and produced in a sustainable manner. 


\section{GONTENTS}

List of tables, maps and illustrations …………....................... vii

Acknowledgements .......................................................... ix

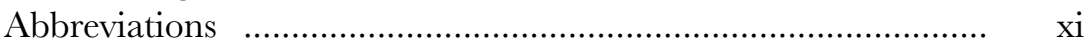

Introduction ….............................................................. xiii

\section{PART I}

Chapter One Witch-hunting in Eichstätt …………............... 3

The background …...............................................................

Witch-hunting in Eichstätt, 1590-1616 ………………........ 15

Witch-hunting in Eichstätt, 1617-1631 …………................ 20

The pattern of witch-hunting in Eichstätt ……................... 27

Chapter Two The witches …………………....................... 45

The authorities and the gender of the witch ……............... 45

The interrogatory and the course of the witch interrogations …........................................................... 51

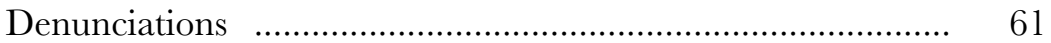

Denunciations - the role of the interrogators ....................... 64

Denunciations - the role of the witch-suspect ....................... 68

The social status of the witch …........................................... 82

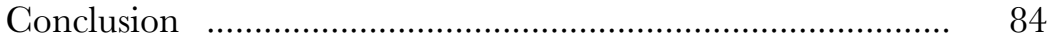

\section{PART II}

Chapter Three Friends and enemies ……............................ 89

Methodology …........................................................ 90

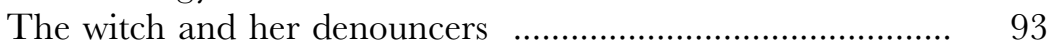

Barbara Haubner and her denouncers .................................. 101

Michael Hochenschildt and his denouncers ……................. 112

Margretha Geiger and her denouncers ……....................... 117

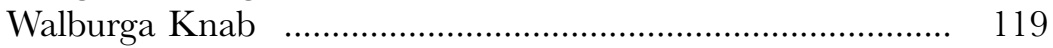

Christoph Lauterer …...................................................... 124

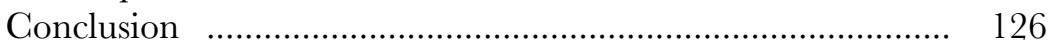


Chapter Four Food and drink …….................................... 129

Food and drink ................................................................. 130

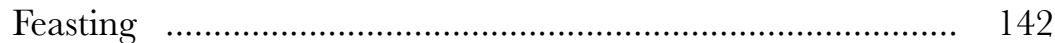

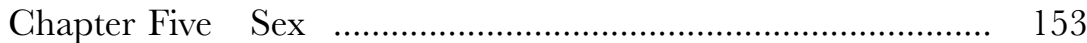

Diabolical seduction …...................................................... 154

Same-sex sexual relations ……............................................ 156

Fornication and adultery ……............................................ 160

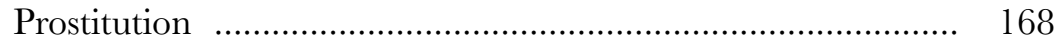

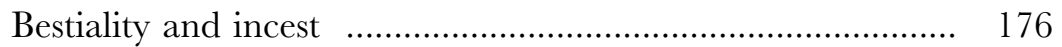

Conclusion ......................................................................... 178

Chapter Six Health ........................................................ 181

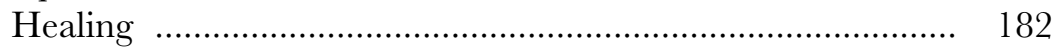

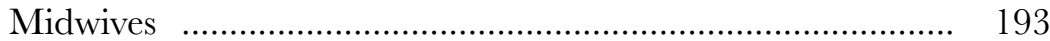

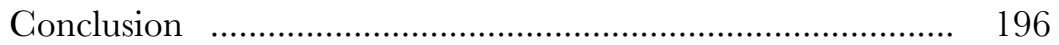

Chapter Seven The abuse of authority …............................ 199

The investigation …........................................................ 200

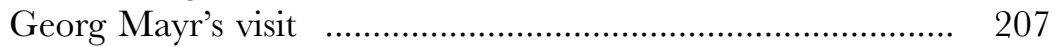

Maria Mayr's infidelity ..................................................... 222

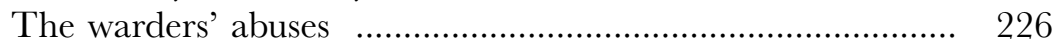

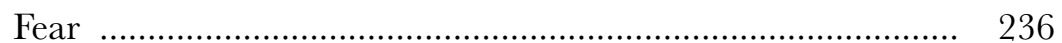

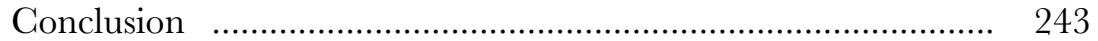

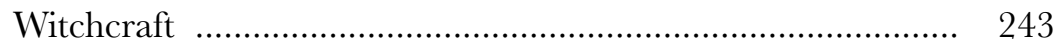

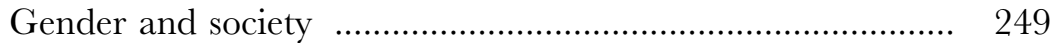

Appendix 1 The interrogatory of 1617 ................................ 255

Appendix 2 Occupations of suspected witches or their

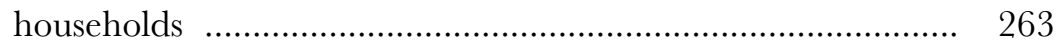

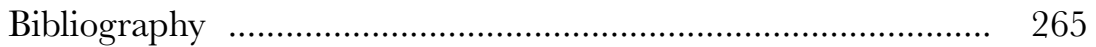

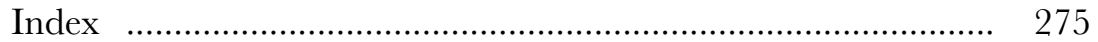




\section{LIST OF TABLES, MAPS AND ILLUSTRATIONS}

\section{Tables}

Table 1. Numbers of women and men suspected of witchcraft in the prince-bishopric of Eichstätt, 1590-1631.

Table 2. Rate of prosecutions in Eichstätt, 1617-31, based on confirmed cases.

\section{Maps}

Map 1. The prince-bishopric of Eichstätt.

Map 2. The town of Eichstätt and the villages in its vicinity.

\section{Illustrations}

Ill. 1. 'Witches' sabbath', woodcut, from Johannes Praetorius, BlockesBerges Verrichtung (1668). Herzog August Bibliothek, Wolfenbüttel [M: Hr 335 (2)]. Reproduced with kind permission.

Ill. 2. Reproduction of a view of Eichstätt, c. 1600, from Franz Xaver Lang, Topographische Beschreibung und Geschichte der königl. Baier. Kreishauptstadt Eichstätt (Eichstätt: Philipp Bronner, 1815), between pp. 78 and 79. British Library, London [10240. aaa.29]. Reproduced with kind permission.

Ill. 3. Daniel Hopfer, 'Peasants at a village feast', sixteenth century, woodcut. Germanisches Nationalmuseum, Nuremberg [Inv. Nr. 11372 Kps. 1466]. Reproduced with kind permission.

Ill. 4. 'Aristotle and Phyllis', section from Peter Flötner, 'The Power of Womanhood', early sixteenth century, woodcut. Kunstsammlungen der Veste Coburg [Geisberg Nr. 818, Inv. No. XV/1, 168-171]. Reproduced with kind permission.

Ill. 5. Nikolaus Manuel Deutsch, 'Old witch', late sixteenth century, drawing. Bildarchiv Preußischer Kulturbesitz, Berlin [BPK 42788]. Reproduced with kind permission. 
J.B. Durrant - 9789047420552

Downloaded from Brill.come4/26/2023 12:18:27PM via free access 


\section{ACKNOWLEDGEMENTS}

My thanks go first to Lyndal Roper who has guided this project over many years and been more generous with her time and support than a supervisor should have. Michael Hunter, Wolfgang Behringer, Justin Champion, Sandra Cavallo, Penelope J. Corfield and the late Alan Bray have offered much advice and encouragement at various points along the way. Dr Karl-Engelhardt Klaar, former director of the Staatsarchiv in Nuremberg, Prof Dr Klaus Walter Littger of the Library of the Catholic University of Eichstätt-Ingolstadt, Dr Bruno Lengenfelder of the Diözesanarchiv Eichstätt and their colleagues were generous with their knowledge of the archives and the early modern history of Eichstätt.

I am grateful to the following institutions which helped fund the project: Royal Holloway for two scholarships; the German Academic Exchange Service for a Goethe-Institut Language Course Scholarship; the German Historical Institute London for a Postgraduate Research Scholarship; the Institute of Historical Research, University of London, for a Scouloudi History Research Fellowship; and King's College, University of London, for a Post-doctoral Fellowship.

The convenors and participants of several seminars and conferences have been invaluable in shaping the project. These include the Postgraduate Seminar on Theory and Method, and the seminars on Society, Culture and Belief, 1500-1800 and European History, 15001800 (all held at the Institute of Historical Research), the Postgraduate Students' Conference, German Historical Institute London (1996), the 'Reading Witchcraft' conference, University of Wales, Swansea (1998), the 'Kiss in History' conference, Bedford Centre for the History of Women, Royal Holloway and the Institute of Historical Research (2000), the 'Witchcraft in Context' conference, University of York (2002), and the Forum on Early Modern Central Europe.

William, Adam and Toben have given me space and distraction when I have needed them most, but for her patience, encouragement and love, I dedicate this book to Julia. 
J.B. Durrant - 9789047420552

Downloaded from Brill.come4/26/2023 12:18:27PM via free access 


\section{ABBREVIATIONS}

BundesA ASt Frankfurt Bundesarchiv Aussenstelle Frankfurt

DiöAE

Diözesanarchiv Eichstätt

ERO

Essex Record Office

StAN

Staatsarchiv Nürnberg 